\title{
PENDEKATAN PEMBELAJARAN KONFLIK KOGNITIF UNTUK MENINGKATKAN PENGUASAAN KONSEP SISWA SMA PADA TOPIK SUHU DAN KALOR
}

\author{
Judyanto Sirait \\ Program Studi Pendidikan Fisika,FKIP, Universitas Tanjungpura
}

\begin{abstract}
The goal of this research is to obtain the gain of student's conceptual understanding in applied cognitive conflict approach in heat and temperature. Method of the research is experiment that conducted at $10^{\text {th }}$ grade in one of senior high school in Bandung. Cognitive conflict approach was used on experiment group while control group used conventional approach. Data were collected through pretest, posttest, questionaire, and observation sheet. Data was analized statistically by t-test. The result showed that normalized gain of conceptual understanding of experiment group and control group $0.57,0.35$ respectively. It showed that average of normalized gain of experiment group is higher than that of control group significantly. The conclusion of the research was cognitive conflict approach increase student's conceptual understanding. Besides that student's and teacher's responses gave positively.
\end{abstract}

Key words: cognitive conflict, conceptual understanding

Fisika merupakan salah satu cabang IPA yang pada dasarnya bertujuan untuk mempelajari dan menganalisis pemahaman kuantitatif gejala dan proses alam dan sifat zat serta penerapannya. Pendapat tersebut diperkuat oleh pernyataan bahwa fisika merupakan suatu ilmu pengetahuan yang mempelajari bagian-bagian dari alam dan interaksi yang ada didalamnya. Ilmu fisika membantu kita untuk menguak dan memahami tabir misteri alam semesta ini (Surya, 1997).

Kurikulum SMA menunjukkan bahwa suhu dan kalor merupakan suatu materi yang dipelajari di kelas $\mathrm{X}$ dimana pokok bahasannya adalah suhu dan termometer, pemuaian, kalor, perubahan wujud, dan perpindahan kalor. Materi ini menjadi dasar bagi siswa yang akan mempelajari termodinamika di kelas
XI. Materi ini sebelumnya sudah pernah dibahas di SMP sehingga siswa sudah memiliki konsep tentang suhu dan kalor. Tetapi kenyataannya di lapangan bahwa, masih banyak siswa yang mengalami kesalahan konsep sehingga siswa mengalami kesulitan dalam memecahkan persoalan yang berhubungan dengan materi tersebut.

Sejumlah peneliti telah meneliti miskonsepsi siswa mengenai suhu dan kalor. Yeo \& Zadnik (2001), mengidentifikasi miskonsepsi yang dialami siswa pada materi suhu dan kalor. Hasilnya adalah kalor bukanlah energi, kalor dan suhu adalah sesuatu yang sama, kalor tidak dapat diukur, tubuh seseorang dalam keadaan dingin tidak memiliki kalor, suhu dapat ditransfer, suhu adalah sifat khusus yang dimiliki materi atau 
benda, air tidak dapat mencapai suhu $0^{\circ} \mathrm{C}$.

Suparno (2005), menyatakan bahwa miskonsepsi yang sering dialami oleh siswa yaitu: suhu dan kalor itu sama, kalor bukanlah energi, mendidih adalah suhu tertinggi yang dapat dicapai suatu benda, suhu adalah sifat dari suatu materi, benda yang berlainan suhu dan berkontak satu sama lain tidak harus menuju suhu yang sama. Benda yang mempunyai suhu lebih tinggi selalu mempunyai kalor yang lebih tinggi pula, es tidak dapat berubah suhu.

atas $\begin{array}{cc}\text { Berdasarkan } & \text { permasalahan di } \\ \text { perlu } & \text { dikembangkan }\end{array}$
pembelajaran yang dapat membantu siswa untuk memperbaiki konsepnya dan melibatkan siswa dalam proses perbaikan tersebut. Salah satunya adalah melalui pendekatan pembelajaran konflik kognitif. Melalui pendekatan konflik kognitif, siswa dihadapkan pada situasi yang bertentangan dengan konsepnya kemudian siswa diarahkan kepada percobaan atau demonstrasi untuk membuktikan kebenaran konsep tersebut. Dalam pembelajaran ini siswa diberi kesempatan untuk mengungkapkan konsepsinya dan mengkritisi yang berbeda dengan konsepsinya. Berpikir kritis tidak hanya sekedar menerima informasi dari pihak lain, tapi juga melakukan pencarian, dan bila diperlukan akan menangguhkan keputusan sampai ia yakin bahwa informasi itu sesuai dengan penalarannya dan didukung oleh bukti atau informasi. Orang yang memiliki keterampilan berpikir kritis, akan mampu mengevaluasi, membedakan dan menentukan apakah suatu informasi benar atau salah.
Pembelajaran yang mengakomodasi perbedaan, bersifat terbuka dan memberikan rangsangan akan lebih efektif dalam membantu siswa membangun ilmu pengetahuannya. Teori konstruktivisme Piaget menyatakan ketika seseorang membangun ilmu pengetahuannya, maka untuk membentuk keseimbangan ilmu yang lebih tinggi diperlukan asimilasi, yaitu kontak atau konflik kognitif yang efektif antara konsep lama dengan kenyataan baru. Rangsangan konflik kognitif dalam pembelajaran akan sangat membantu proses asimilasi menjadi lebih efektif dan bermakna dalam mengembangkan intelektualitas siswa.

Hasil penelitian Partono (2001), menunjukkan bahwa strategi konflik kognitif dapat membuat siswa lebih termotivasi dalam belajar, mengubah konsepsi siswa yang salah menjadi konsepsi ilmiah dan meningkatkan penguasaan konsep siswa pada topik gerak dan gaya. Baser (2006) meneliti tentang pembelajaran berbasis konflik kognitif untuk mengubah konsepsi siswa pada topik suhu dan kalor, hasilnya adalah peningkatan pemahaman konsep siswa yang belajar dengan konflik kognitif lebih tinggi dari siswa yang belajar dengan konvensional. Pembelajaran berbasis konflik kognitif lebih baik memperbaiki konsep suhu dan kalor siswa dibanding dengan pembelajaran konvensional. Kim et al (2006) meneliti tentang konflik kognitif dan perubahan konsep siswa dalam fisika dengan kelas inkuiri. Hasil penelitian menunjukkan bahwa tingkat pemahaman awal siswa memegang peranan penting dalam pemahaman konsep di kelas inkuiri. Siswa yang 
memiliki respon untuk meninjau kembali teori yang ada dengan motivasi yang tinggi dapat meningkatkan pemahaman ketika menghadapi situasi konflik kognitif dalam kelas inkuiri. Sugiyanta (2008), hasil penelitiannya menunjukkan pendekatan konflik kognitif dalam pembelajaran fisika mempuyai pengaruh yang berarti meningkatkan hasil belajar siswa dan meningkatkan kualitas lingkungan belajar di dalam kelas lebih kondusif.

\section{Metode Penelitian}

Tujuan dari artikel ini adalah untuk mengetahui sejauh manakah pendekatan pembelajaran konflik kognitif dapat meningkatkan penguasaan konsep siswa pada materi suhu dan kalor. Metode penelitian yang digunakan adalah eksperimen semu dan deskriptif. Metode eksperimen digunakan untuk melihat peningkatan penguasaan konsep, sedangkan metode deskriptif digunakan untuk mendapatkan gambaran tentang tanggapan guru dan siswa terhadap pendekatan konflik kognitif. Kelas eksperimen menggunakan pendekatan pembelajaran konflik kognitif, sedangkan kelas kontrol menggunakan pendekatan pembelajaran konvensional.

Sampel penelitian adalah siswa kelas X di salah satu SMA di kota Bandung berjumlah 56 orang, dimana masing-masing kelas yaitu kelas eksperimen dan kelas kontrol terdiri dari 28 orang. Penelitian dilaksanakan semester genap tahun pelajaran 2008/2009.

Instrumen penelitian yang digunakan adalah tes penguasaan konsep suhu dan kalor yang berjumlah 25 soal yang diberikan sebelum dan setelah pembelajaran, lembar observasi yang digunakan untuk mengamati sejauh mana pendekatan pembelajaran konflik kognitif yang direncanakan dalam proses belajar mengajar, dan angket respon siswa dan guru yang digunakan untuk memperoleh informasi tentang tanggapan siswa dan guru terhadap penggunaan pendekatan pembelajaran konflik kognitif yang diterapkan.

\section{Hasil Penelitian}

\section{Penguasaan Konsep}

Hasil perhitungan skor rata-rata tes awal siswa kelas eksperimen sebesar 8,75 (35\%), sementara skor rata-rata tes awal pada kelas kontrol sebesar 8,89 (36\%). Hal ini menunjukkan bahwa perolehan skor rata-rata tes awal penguasaan konsep siswa kedua kelas hampir sama. Selanjutnya skor rata-rata tes akhir untuk kelas eksperimen sebesar 17,86 (71\%), dan skor rata-rata tes akhir kelas kontrol sebesar 14,36 (57\%). Hal ini menunjukkan bahwa penguasaan konsep siswa setelah mengikuti pembelajaran mengalami peningkatan tetapi penguasaan konsep siswa kelas eksperimen lebih tinggi dari kelas kontrol.

Hasil perhitungan skor ratarata gain yang dinormalisasi penguasaan konsep kelas eksperimen sebesar 0,57 dalam kategori sedang, dan kelas kontrol sebesar 0,35 dalam kategori rendah. Dengan demikian prosentase gain yang dinormalisasi penguasaan konsep kelas eksperimen lebih tinggi dibanding dengan kelas kontrol. Prosentase skor rata-rata tes awal, tes akhir, dan gain yang dinormalisasi penguasaan konsep 
suhu dan kalor antara kelas diperlihatkan pada Gambar 1. eksperimen dan kelas kontrol

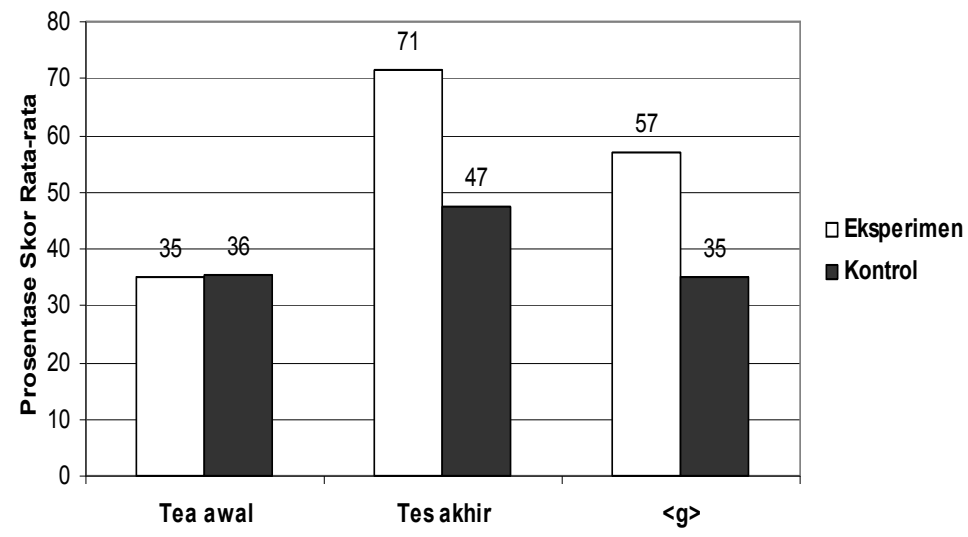

Gambar 1. Perbandingan prosentase skor rata-rata tes awal, tes akhir dan $<\mathrm{g}>$ penguasaan konsep suhu dan kalor

Untuk mengetahui perbandingan peningkatan penguasaan konsep antara siswa kelas eksperimen dan kelas kontrol, dilakukan analisis terhadap data $<\mathrm{g}>$, yang meliputi uji normalitas, homogenitas dan uji-t. Uji normalitas $\quad<\mathrm{g}>$ untuk kelas eksperimen diperoleh $\chi_{\text {hitung }}^{2}=0,45$ dan $\chi_{\text {tabel }}^{2}=7,81$ untuk taraf signifikansi 0,05 . Ternyata $\chi_{\text {hitung }}^{2}<$ $\chi_{\text {tabel, }}^{2}$ hal ini menunjukkan data $<\mathrm{g}>$ kelas eksperimen berdistribusi normal. Sedangkan untuk kelas kontrol diperoleh $\chi_{\text {hitung }}^{2}=3,50$ dan $\chi_{\text {tabel }}^{2}=7,81$ untuk taraf signifikansi 0,05 . Ternyata $\chi_{\text {hitung }}^{2}<\chi_{\text {tabel, }}^{2}$ hal ini menunjukkan data $<\mathrm{g}>$ kelas kontrol berdistribusi normal.

Uji homogenitas $\quad<\mathrm{g}>$ penguasaan konsep kelas eksperimen dan kelas kontrol diperoleh $\mathrm{F}_{\text {hitung }}=$ 1,5 dan $\mathrm{F}_{\text {tabel }}=1,9$ untuk taraf signifikansi 0,05 . Ternyata $F_{\text {hitung }}<$ $F_{\text {tabel, }}$, hal ini menunjukkan bahwa distribusi data kedua kelas tersebut adalah homogen.

Karena kedua kelompok tersebut berdistribusi normal dan homogen, maka pengolahan data dilanjutkan ke uji-t. Dari hasil uji-t $<$ g $>$ penguasaan konsep kelas eksperimen dan kelas kontrol diperoleh bahwa $t_{\text {hitung }}=5,5$ dan $t_{\text {tabel }}$ $=1,67$. Ternyata $t_{\text {hitung }}>t_{\text {tabel, }}$ ini berarti bahwa peningkatan penguasaan konsep kelas eksperimen lebih tinggi dibandingkan dengan peningkatan penguasaan konsep kelas kontrol. Dengan demikian pembelajaran dengan pendekatan konflik kognitif secara signifikan dapat lebih meningkatkan penguasaan konsep siswa dibanding dengan pembelajaran konvensional.

Materi suhu dan kalor yang diteliti terdiri dari lima sub konsep yaitu konsep suhu, pemuaian, kalor, perubahan wujud dan perpindahan kalor. Setiap sub konsep dianalisis ketercapaiannya berdasarkan skor tes awal, tes akhir dan $<\mathrm{g}>$.

Berdasarkan hasil perhitungan diperoleh bahwa untuk kelas eksperimen prosentase terendah pada konsep perubahan wujud sebesar $31 \%$ dan tertinggi pada konsep suhu sebesar $40 \%$, sedangkan prosentase terendah setelah dilakukan tes akhir 
terjadi pada konsep pemuaian sebesar $62 \%$ dan prosentase tertinggi pada konsep suhu sebesar 78\%.

Peningkatan penguasaan konsep tertinggi terjadi pada konsep kalor sebesar $63 \%$ dan terendah pada konsep pemuaian sebesar 35\%.

Untuk kelas kontrol prosentase terendah skor penguasaan konsep pada saat tes awal terjadi pada konsep perubahan wujud sebesar $31 \%$ dan tertinggi pada konsep suhu sebesar $46 \%$, sedangkan prosentase terendah setelah dilakukan tes akhir terjadi pada konsep kalor sebesar 52\% dan tertinggi pada konsep suhu 65\%. Peningkatan penguasaan konsep tertinggi terjadi pada konsep perubahan wujud sebesar $41 \%$ dan terendah pada konsep kalor sebesar $21 \%$. Prosentase peningkatan penguasaan konsep kelas eksperimen dan kelas kontrol untuk setiap sub konsep suhu dan kalor diperlihatkan pada Gambar 2 .

\section{Tanggapan Siswa dan Guru terhadap Pendekatan Pembelajaran Konflik Kognitif}

Untuk mengetahui tanggapan siswa terhadap penerapan pendekatan pembelajaran konflik kognitif, dilakukan dengan memberikan angket kepada siswa. Berdasarkan analisis diketahui bahwa setiap indikator yang diukur, siswa memberikan tanggapan yang positif yaitu menyatakan setuju terhadap penerapan pendekatan pembelajaran konflik kognitif. Siswa menyatakan setuju bahwa pembelajaran tersebut dapat meningkatkan penguasaan konsep. Disamping itu, siswa juga setuju bahwa pendekatan pembelajaran ini merupakan baru bagi siswa dan dapat meningkatkan motivasi mereka untuk belajar. Melalui angket yang dibagikan, siswa ingin agar pendekatan pembelajaran seperti ini bisa diterapkan pada materi yang lain.

Untuk mengetahui tanggapan guru yang mengajarkan pendekatan pembelajaran konflik kognitif ini, dilakukan dengan memberikan angket kepada guru yang berisi sejumlah pertanyaan. Berdasarkan hasil analisis diketahui bahwa guru memiliki tanggapan yang positif juga yang berarti sangat setuju bahwa pendekatan pembelajaran konflik kognitif dapat meningkatkan penguasaan konsep siswa. Disamping itu guru juga setuju bahwa pendekatan pembelajaran dapat mengaktifkan siswa dalam belajar.

\section{Pembahasan}

Pendekatan pembelajaran konflik kognitif yang diterapkan dalam penelitian ini terdiri dari empat fase yaitu orientasi siswa pada konflik, melakukan penyelidikan melalui percobaan, menyajikan hasil percobaan dan kesimpulan, dan menganalisis serta mengevaluasi. Pada fase orientasi siswa pada konflik, siswa diberikan sejumlah pertanyaan dan siswa diminta untuk memberikan prediksi atau jawaban sementara. Kemudian dilanjutkan ke fase penyelidikan melalui percobaan. Pada fase ini siswa melakukan penyelidikan untuk mengetahui kebenaran konsep yang ditanyakan sebelumnya, membuat analisis dan kesimpulan serta menjawab kembali pertanyaan sebelumnya. Siswa diberi kesempatan untuk menyajikan hasil dan kesimpulan pada fase menyajikan hasil. Untuk fase terakhir yaitu menganalisis dan evaluasi, guru mengevaluasi hasil analisis, kesimpulan,jawaban siswa dan 
memberikan kesempatan kepada siswa untuk bertanya.

$$
\text { Penguasaan konsep adalah }
$$
kemampuan menerangkan sesuatu dengan kata-kata sendiri, mengenal sesuatu yang dinyatakan dengan katakata yang berbeda dengan kata-kata yang terdapat dalam buku teks (Baharudin, 1982). Ada tiga aspek yang berhubungan dengan penguasaan konsep yaitu: kemampuan menerangkan atau menjelaskan, pengenalan, dan kemampuan menginterpretasi.

Tes penguasaan konsep diberikan sebelum dan sesudah pembelajaran baik untuk kelas eksperimen maupun kelas kontrol. Adapun sub konsep dari suhu dan kalor yang diteliti adalah suhu dan termometer, pemuaian, kalor, perubahan wujud, dan perpindahan kalor. Analisis data tes akhir dan $<\mathrm{g}>$ kedua kelas dilakukan untuk melihat sejauh mana peningkatan penguasaan konsep kedua kelas.

Dari hasil analisis diperoleh bahwa gain yang dinormalisasi penguasaan konsep untuk kelas eksperimen $(0,57)$ lebih tinggi dibandingkan kelas kontrol $(0,35)$. Hasil ini menunjukkan bahwa pendekatan pembelajaran konflik kognitif yang direncanakan dan dilakukan dengan baik dapat lebih meningkatkan penguasaan konsep siswa dibandingkan dengan pembelajaran

konvensional.Peningkatan

penguasaan konsep siswa kelas eksperimen tertinggi pada sub konsep kalor sebesar $63 \%$ dan terendah pada sub konsep pemuaian sebesar 35\%. Untuk kelas kontrol peningkatan penguasaan konsep tertinggi pada sub konsep perubahan wujud sebesar $41 \%$ dan terendah pada sub konsep kalor sebesar $21 \%$.

Sub konsep kalor mengalami peningkatan tertinggi untuk kelas eksperimen sementara terendah untuk kelas kontrol. Hal ini dimungkinkan karena percobaan pada pembelajaran kalor lebih sederhana, terbukti dari hasil observasi menunjukkan bahwa siswa tidak mengalami kesulitan atau kebingungan dalam melakukan percobaan sehingga siswa lebih mudah melakukannya. Disamping itu percobaan kalor ini sudah pernah dialami siswa dalam kehidupan sehari-harinya. Hal yang lain adalah karena soal-soal sub konsep kalor berhubungan dengan percobaan. Pada pendekatan pembelajaran konflik kognitif siswa mempunyai kesempatan untuk melakukan penyelidikan setiap percobaan, membuat analisis setiap percobaan, dan diakhiri dengan evaluasi dari guru. Hal ini menunjukkan bahwa pendekatan pembelajaran sangat membantu siswa untuk menguasai konsep dengan adanya percobaan dan evaluasi dari guru sehingga siswa lebih memahami konsep tersebut.

Menurut Downey (Partono, 2001), dengan menghadapkan siswa pada gagasan atau situasi baru yang bertentangan dengan pemahaman sebelumnya, maka setelah melakukan eksperimen atau demonstrasi, memicu proses rekonstruksi konsep-konsep dalam stuktur kognitifnya sehingga dapat meningkatkan pemahaman konsep.

Pendekatan konflik kognitif memberikan kesempatan kepada siswa untuk mengungkapkan konsepsinya. Ketika konsepsi siswa bertentangan dengan konsep ilmiah, siswa merasa tidak puas. 
Ketidakpuasan siswa menuntun penyelidikan melalui eksperimen.

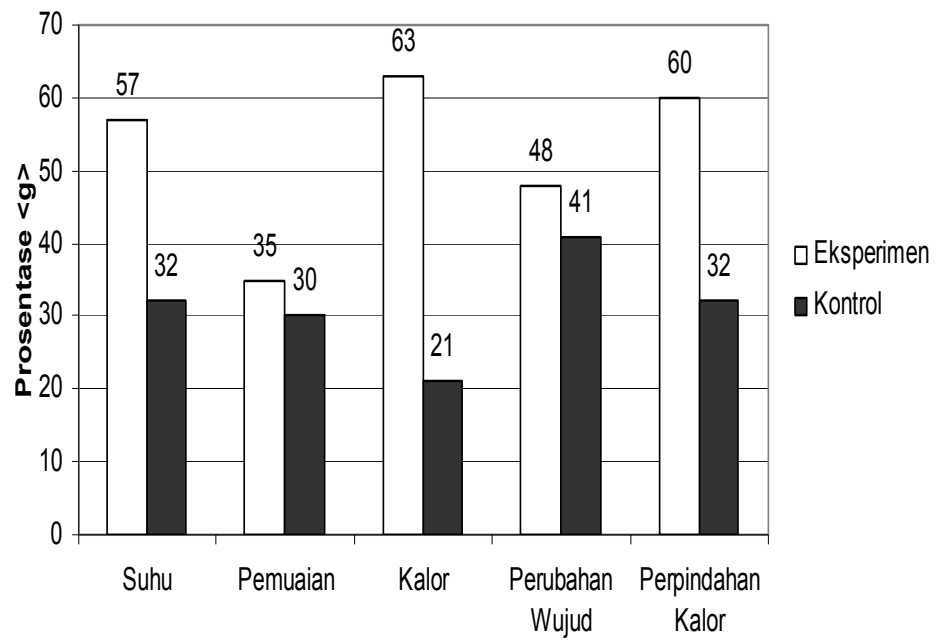

Gambar 2. Prosentase peningkatan penguasaan konsep setiap sub konsep

Hasil percobaan yang mereka dapatkan dapat membantu siswa untuk memperbaiki konsepnya. Apabila siswa masih belum yakin, maka guru membantu dalam proses perbaikan konsep siswa. Dengan demikian siswa memiliki konsep yang benar yang akhirnya dapat meningkatkan penguasaan konsep.

\section{Rendahnya} peningkatan penguasaan konsep kelas eksperimen pada sub konsep pemuaian mungkin disebabkan percobaan pemuaian. Pada kegiatan yaitu percobaan muai panjang, pertambahan panjang benda sangat kecil sehingga siswa mengalami kesulitan dalam mengamatinya. Beberapa kelompok kurang teliti dalam mengamati pertambahan panjang benda ketika dipanaskan untuk dua bahan yang berbeda, sehingga siswa mengalami kesalahan dalam menganalisis dan membuat kesimpulan. Pada kegiatan percobaan muai volum, beberapa kelompok memberikan alasan yang kurang lengkap. Disamping itu pada fase analisis dan evaluasi, guru membatasi pertanyaan siswa, sehingga kebingungan yang dialami siswa belum terjawab. Guru tidak memiliki waktu yang cukup untuk memberikan penguatan kepada siswa. Alasan lain yang menyebabkan kemampuan kedua kelas tidak jauh berbeda karena kelas kontrol terlatih dengan persoalan matematis, sementara kelas ekperimen kurang terlatih, tetapi secara konseptual kelas ekperimen memiliki kemampuan lebih tinggi dari kelas kontrol.

Peningkatan penguasaan konsep pada sub konsep perubahan wujud untuk kedua kelas tidak jauh berbeda. Hal ini dimungkinkan karena percobaan perubahan wujud yaitu untuk membuktikan bahwa suhu benda tidak mengalami perubahan ketika mengalami perubahan wujud, beberapa kelompok memperoleh data yang berbeda dari yang diharapkan karena percobaan ini membutuhkan ketelitian yang tinggi. Oleh karena itu siswa tidak berhasil dalam membuat 
grafik dan membuat kesimpulan tentang perubahan wujud. Pada fase analisis, guru tidak memberikan alasan yang kuat kepada pertanyaan siswa tentang mengapa suhu benda tidak mengalami perubahan ketika diberikan kalor, disamping itu pertanyaan siswa dibatasi oleh guru karena waktu yang terbatas. Sementara untuk kelas kontrol, materi perubahan wujud ditekankan pada kemampuan siswa untuk membaca grafik, sehingga siswa lebih terlatih dalam membaca grafik. Namun demikian, siswa kelas eksperimen masih memiliki kemampuan lebih tinggi dari kelas kontrol karena siswa pada pembelajaran konflik kognitif ikut terlibat langsung dalam proses pembuatan grafik perubahan wujud.

Untuk memahami suatu konsep perlu diperhatikan bagaimana konsep tersebut disajikan dan terlibat langsung dalam proses pencapaian konsep tersebut. Dengan menyajikan benda-benda yang konkret lebih memudahkan dalam pencapaian suatu konsep (Dahar, 1996). Pendekatan konflik kognitif dapat menyajikan benda-benda konkret dalam mempelajari suatu konsep yaitu melalui percobaan. Siswa diperhadapkan pada situasi nyata yaitu melalui percobaan dan terlibat langsung dalam proses pencapaian konsep tersebut.

Berdasarkan teori perubahan konsep, pengetahuan dibentuk oleh siswa secara terus menerus. Seorang siswa dapat salah mengerti dalam menangkap suatu konsep yang dipelajari. Pengertian yang salah dalam memahami suatu konsep, bukanlah akhir dari segala-galanya, melainkan menjadi awal untuk perkembangan yang lebih baik.
Ketika menghadapi pengalaman baru yang tidak cocok dengan skema yang dimiliki, siswa mengadakan penyesuaian dengan beragam kemungkinan, misalnya dengan menambah atribut baru, memperhalus, memperluas, atau mengubah skema lamanya (Suparno, 1997).

\section{Kesimpulan}

Peningkatan penguasaan konsep siswa dengan pendekatan pembelajaran konflik kognitif $(0,57)$ secara signifikan lebih tinggi dibandingkan peningkatan penguasaan konsep siswa dengan pembelajaran konvensional (0,35). Dengan demikian penerapan pendekatan pembelajaran konflik kognitif dapat lebih meningkatkan penguasan konsep pada materi suhu dan kalor dibanding dengan pembelajaran konvensional. Tanggapan guru dan sebagian besar siswa terhadap penerapan pendekatan pembelajaran konflik kognitif adalah positif, dan berharap penggunaannya pada materi fisika yang lain.

\section{Daftar Pustaka}

Baharuddin. (1982). "Peranan dasar intelektual sikap dan pemahaman dalam fisika terhadap kemampuan siswa di Sulawesi Selatan membangun model mental". Disertasi Doktor FPS IKIP Bandung: Tidak diterbitkan

Baser, M. (2006). "Fostering Conceptual Change by Cognitive Conflict Based Instruction Student's Understanding of Heat and Temperature Concept". 
Eurasia Journal of Mathematics, Science and Technology Education, Vol 2(2)

Baser, M. (2006). "Effect of Conceptual Change Oriented Instruction on Student's Understanding of Heat and Temperature Concepts". Journal of Maltese Education Research, Vol 4 (1), 64-79

Dahar,R.W， 1996， Teori-Teori Belajar, Jakarta: Erlangga

Kim et al. (2006). "Student's Cognitive Conflict and Conceptual Change in Physics by Inquiry Class". American Institute of Physics. 0-7354-0311-2/06

Partono. (2001). "Pengaruh Strategi Konflik Kognitif dalam Pembelajaran Fisika terhadap Pemahaman Siswa tentang
Gerak dan Gaya". Tesis Magister PPS UPI: Tidak diterbitkan

Sugiyanta. (2008). Pendekatan Konflik Kognitif dalam Pembelajaran Fisika. Tersedia: http://www.lpmpjogja.diknas. go.id

Suparno. (2005). Miskonsepsi dan Perubahan Konsep dalam Pendidikan Fisika. Jakarta: PT. Gramedia Widiasarana

Surya, Yohanes. (1997). Olimpiade Fisika. Jakarta : Primatika Cipta Ilmu.

Yeo, S \& Zadnik, M. (2001). "Introductory Thermal Concept Evaluation: Assessing Student's Understanding". The Physics Teacher, Vol 39, 496-504 